\title{
TUBOCURARINE BINDING IN UNDERCUT CEREBRAL CORTEX AND THE EFFECT OF LONG-TERM ELECTRICAL STIMULATION
}

\author{
NAI-SHIN CHU*, L. T. RUTLEDGE AND O. Z. SELLINGER
}

Department of Physiology and Mental Health Research Institute, University of Michigan, Ann Arbor, Mich. 48104 (U.S.A.)

(Accepted December 22nd, 1970)

\section{INTRODUCTION}

Several mechanisms have been proposed to explain prolonged epileptiform afterdischarge, elicited by various forms of stimulation in chronically isolated cerebral cortex: (1) loss of a muscarinic inhibitory mechanism ${ }^{26}$, (2) decrease in the enzyme activity responsible for inactivating transmitter substance ${ }^{21}$, (3) proliferation of axon collaterals ${ }^{20}$, (4) deafferentation of inhibitory stellate cells ${ }^{22}$, and (5) denervation (or 'disuse') supersensitivity to putative transmitters ${ }^{13,24}$. Which one or more of these is most implicated is still an open question.

The last mechanism was investigated in the present study because it is related to epilepsy and to the theory of plasticity and learning in the central nervous system. Although undercut cortex is a deafferentated and deefferentated preparation, the characteristic loss of dendritic spines in the surviving neurons is a consequence of deafferentation ${ }^{19}$ and of 'disuse' of synapses ${ }^{22}$. This interpretation is supported by Valverde's light deprivation studies ${ }^{25}$. There are also instances of enhanced synaptic responses following deafferentation or disuse in the spinal cord ${ }^{1,3}$.

To test the hypothesis of disuse supersensitivity, we have taken advantage of two facts. First, it is possible to isolate fractions rich in 'cholinergic' synaptic membranes by the subcellular fractionation technique of De Robertis et al. 7,12 , in which the isolated nerve ending complexes often have postsynaptic membranes attached. Second, changes in acetylcholine ( $\mathrm{ACh}$ ) receptor density in 'cholinergic' postsynaptic membranes can be indirectly detected by binding with cholinergic blocking agents such as tubocurarine ${ }^{8}$. Using this approach we observed that the 'cholinergic' synaptic membranes of the undercut cortex bound more dimethyl- $\left[{ }^{14} \mathrm{C}\right]$-D-tubocurarine than the corresponding membranes of the contralateral cortex. Furthermore, long-term electrical stimulation tended to prevent the elevation in binding noted in the undercut cortex.

* Present address: Laboratory of Neuropharmacology, Division of Special Mental Health Research, National Institute of Mental Health, St. Elizabeths Hospital, Washington, D.C. 20032, U.S.A. 
METHODS

The methods for preparing chronic animals with undercut cortices, the determination of supersensitivity and the isolation of subcellular fractions are described in the accompanying paper ${ }^{6}$. Tissue from the same animals ( 3 with undercut cortices, 5 with stimulated undercut cortices) was used for the binding experiments. Except for a control experiment, only the membrane fraction $1.0 \mathrm{M}$ which is rich in acetylcholinesterase (AChE) activity7,23 was used. The cholinergic blocking agent was dimethyl[ ${ }^{14} \mathrm{C}$-D-tubocurarine with a specific activity of $108 \mathrm{mCi} / \mathrm{mmole}$ (Amersham/Searle, Des Plaines, Ill.). The radiochemical purity was determined by obtaining a single radioactive spot upon thin-layer chromatography on silica gel in ethanol-10\% aqueous $\mathrm{HCl}(9: 1, \mathrm{v} / \mathrm{v})$.

The in vitro technique of Azcurra and De Robertis ${ }^{2}$ was adopted for studying the uptake of the radioactive cholinergic blocking agent by the $1.0 \mathrm{M}$ membranes. Since the measurements were routinely made in triplicate only 2 tissue level samples each from the undercut and the contralateral cortex were simultaneously studied within a single experiment. Twenty-five and $50 \mu \mathrm{l}$ of the $1.0 \mathrm{M}$ membrane suspension at a protein concentration of about $1 \mathrm{mg} / \mathrm{ml}$ were incubated with a known amount of the radioactive drug in $1 \mathrm{ml}$ of Tris-buffer $(0.05 M$, pH 7.2) in $0.25 M$ sucrose in $11 \mathrm{ml}$ polyallomer (Spinco Co., Palo Alto, Calif.) centrifuge tubes. The final concentration of dimethyl-[14C]-D-tubocurarine was $5 \cdot 10^{-7} M$. After incubation at $37^{\circ} \mathrm{C}$ for $15 \mathrm{~min}$, the binding reaction was terminated by adding $10 \mathrm{ml}$ of ice-cold $0.25 M$ sucrose. The tubes were centrifuged at $125,000 \times g$ for $50 \mathrm{~min}$. Two additional sucrose washes and centrifugations yielded a pellet which was suspended in $1 \mathrm{ml}$ of distilled $\mathrm{H}_{2} \mathrm{O}$. The radioactivity in the third sucrose wash was close to background. The suspension of the final pellet was transferred to a scintillation vial to which was added $2 \mathrm{ml}$ of Bio-Solv3 (Beckman Co., Fullerton, Calif.) and $10 \mathrm{ml}$ of scintillation fluid (toluene, $1000 \mathrm{ml}$; 2,5-diphenyloxazole, $4 \mathrm{~g}$; dimethyl-1,4-bis-(5-phenyloxazolyl-2)-benzene, $100 \mathrm{mg}$ ). The radioactivity was determined with a Nuclear Chicago (Des Plaines, Ill.) Unilux II liquid scintillation spectrometer. The efficiency of counting was $70-80 \%$. Routinely triplicate samples were counted. It was found that the 'cholinergic' receptors ${ }^{10,11}$ lost their binding capacity for dimethyl-[14 $\mathrm{C}]$-D-tubocurarine upon overnight storage at $4^{\circ} \mathrm{C}$. All binding experiments were therefore carried out immediately after isolation of the synaptic membrane preparations.

\section{RESULTS}

It was found that the AChE-rich $1.0 \mathrm{M}$ membranes had the highest binding capacity for dimethyl-[ $\left[{ }^{14} \mathrm{C}\right]-\mathrm{D}$-tubocurarine. In a control study of rat brain cortex, binding of dimethyl-[14 $\mathrm{C}]$-D-tubocurarine by $1.0 \mathrm{M}, 1.2 \mathrm{M}$ and $1.4 \mathrm{M}$ membranes amounted to $7,458,2,740$ and $2,068 \mathrm{disint} . / \mathrm{min} / \mathrm{mg}$ protein respectively, under standard incubation conditions. In a comparable control experiment using the cerebral cortex of a cat samples of $1.0 \mathrm{M}$ and $1.2 \mathrm{M}$ membranes bound dimethyl-[14 C]-D-tubocurarine to the extent of 17,042 and $9,518 \mathrm{disint}$. $/ \mathrm{min} / \mathrm{mg}$ protein. In the same experi- 
ment, boiling of the membrane preparations for $5 \mathrm{~min}$ reduced the binding to 6,292 disint. $/ \mathrm{min} / \mathrm{mg}$ protein in the $1.0 \mathrm{M}$ fraction and to $4,682 \mathrm{disint} . / \mathrm{min} / \mathrm{mg}$ protein in the $1.2 \mathrm{M}$ fraction. The relationship between binding and amount of tissue was close to linear within the range of protein values tested. Other experiments, using rat cerebral cortices, showed that chloralose anesthesia did not affect the binding of dimethyl$\left.{ }^{[14} \mathrm{C}\right]$-D-tubocurarine by the $1.0 \mathrm{M}$ synaptic membranes.

Since the above experiments showed that the AChE-rich synaptic membranes of the $1.0 \mathrm{M}$ fraction ${ }^{6,23}$ also had the highest binding capacity for dimethyl-[ $\left.{ }^{14} \mathrm{C}\right]-\mathrm{D}-$ tubocurarine, this fraction was used throughout this study to compare the undercut and the contralateral, homotopic cortex. Table I shows the binding of dimethyl$\left[{ }^{14} \mathrm{C}\right]$-D-tubocurarine by the $1.0 \mathrm{M}$ membranes of cat cortex. Cortex contralateral and homotopic to the undercut side had a binding capacity of $18,000-19,000 \mathrm{disint} / \mathrm{min} /$ mg protein which corresponds to about $10^{-7}$ mmole/mg protein, a value similar to that reported by De Robertis et al. ${ }^{10}$. Partial isolation of the feline cerebral cortex by undercutting increased the binding capacity of the $1.0 \mathrm{M}$ membranes by $63 \%$ as compared with that of the contralateral cortex (Table I). Tissues treated by long-term electrical stimulation showed increased binding of only $26 \%$, comparing stimulated cortex with contralateral cortex. Although these differences could not be statistically tested for significance, because the number of experiments was small, the trend seems clear. Expressing binding in terms of the specific activity of $\mathrm{AChE}^{6}$ diminishes the difference between the undercut cortex and the contralateral cortex from $63 \%$ to $41 \%$ (Table I). The effects of long-term stimulation are also not as great, only a $10 \%$ difference as compared with the binding of the undercut group.

The two 'most supersensitive' undercut cortices $^{6}$ had a high binding capacity averaging 38,694 disint./min/mg protein for the undercut cortex and 18,239 disint./ $\mathrm{min} / \mathrm{mg}$ protein for the contralateral cortex. For two of the three 'least supersensitive'

\section{TABLE I}

BINDING OF DIMETHYL-[ $\left.{ }^{14} \mathrm{C}\right]$-D-TUBOCURARINE TO THE SYNAPTIC MEMBRANES (FRACTION $1.0 \mathrm{M}$ ) OF CAT CEREBRAL CORTEX

$\mathrm{UC}=$ undercut cortex; $\mathrm{SUC}=$ stimulated undercut cortex; $\mathrm{CC}=$ contralateral cortex.

\begin{tabular}{|c|c|c|c|c|c|}
\hline$C C(3)^{*}$ & $U C(3)$ & $\%$ change & $C C(5)$ & $S U C(5)$ & $\%$ change \\
\hline \multicolumn{6}{|c|}{ Bound dimethyl-[14C]-D-tubocurarine (disint./min $/ \mathrm{mg}$ protein) } \\
\hline $\begin{array}{l}18,144 \\
\pm 494 * *\end{array}$ & $\begin{array}{c}29,678 \\
\pm 928\end{array}$ & +63 & $\begin{array}{c}19,172 \\
\pm 368\end{array}$ & $\begin{array}{c}24,366 \\
\pm 701\end{array}$ & +26 \\
\hline \multicolumn{6}{|c|}{ Bound dimethyl-[ $\left.{ }^{14} \mathrm{C}\right]-\mathrm{D}-$ tubocurarine (disint./min/AChE) ${ }^{* * *}$} \\
\hline $\begin{array}{r}228.2 \\
\pm 38.7\end{array}$ & $\begin{array}{r}321.8 \\
\pm 89.4\end{array}$ & +41 & $\begin{array}{r}234.6 \\
\pm 22.1\end{array}$ & $\begin{array}{r}306.2 \\
\pm 24.7\end{array}$ & +31 \\
\hline
\end{tabular}

* Number of experiments in parentheses.

* * Standard error of the mean.

*** $\Delta$ O.D.412/20 min/mg of protein ${ }^{6}$. 
stimulated undercut cortices the binding for both undercut and contralateral cortices was nearly equal. The third animal was equivocal.

DISCUSSION

The specific binding of dimethyl-[14 $\mathrm{C}]$-D-tubocurarine is suggested by the high affinity of the drug for the $1.0 \mathrm{M}$ fraction, by the linearity between binding and the protein concentration and by the drastic reduction of binding after boiling. In spite of these consistencies, the limitation of the in vitro technique should be considered. The osmotic shock used to rupture the cells and the repeated homogenizations are likely to change the accessibility of the subsynaptic receptors to the cholinergic blocker. Furthermore, the present technique did not allow us to detect changes in the sensitivity of non-synaptic neuronal membranes, such as that observed in skeletal muscle after denervation ${ }^{18}$.

Micro-iontophoretic study has indicated that cholinoceptive cortical neurons possess muscarinic instead of nicotinic receptors ${ }^{15}$. In preliminary experiments, the binding of tritiated atropine to the $1.0 \mathrm{M}$ fraction was found to be low and the undercut cortex did not bind in excess of $10 \%$ more drug than control preparations. It is possible, however, that the binding of atropine in vitro was too weak to survive the isolation procedures.

It is interesting to note that protein of the synaptic membranes was more closely representative of the changes in tubocurarine binding than was the AChE activity of the membranes. Expressing the binding capacity in terms of the specific activity of $\mathrm{AChE}$ thus merely complements the expression of disint./min $/ \mathrm{mg}$ protein without inferring any direct association of the drug with enzyme protein. Yet, since the proteins of the $1.0 \mathrm{M}$ fraction are obviously derived from more than one type of synaptic membrane (even though, admittedly, those constituting the 'cholinergic' AChE-rich type predominate), it is possible that the enhanced binding capacity of the undercut cortex represents a non-specific increase in sensitivity of admixed non-cholinergic synaptic membranes to a cholinergic blocking agent. However, De Robertis et al. have recently described the extraction from AChE-rich synaptic membranes, of a special type of proteolipid implicated as the receptor substance for tuboburarine ${ }^{10,11}$. These workers further observed the relative independence of $\mathrm{AChE}$ and of the overall capacity of the synaptic membranes to bind tubocurarine ${ }^{9}$.

The phenomenon of supersensitivity of the neuronally isolated cortex may be explained by an increased sensitivity of the subsynaptic and, possibly, non-synaptic membranes as a consequence of denervation. This is analogous to the supersensitivity observed in denervated muscle. The suggestion was made more than 30 years ago by Cannon $^{5}$, that abnormality of cortical cells in epilepsy might be the result of loss of innervation of cells - another example of increased sensitivity in denervated structures. A reasonable explanation of the hyperexcitability, repetitive burst firing and of the increased spontaneous firing of neurons near an epileptic irritative focus, indeed seems to be through denervation of the affected cells. This and similar causative mechanism were recently reviewed by Ward ${ }^{27}$. 
It certainly seems unlikely that epileptiform activity of traumatized and denervated mature cortex can be explained by proliferation of axon collaterals ${ }^{22}$ or directly as a result of a decrease in transmitter inactivating enzyme. Loss of an inhibitory mechanism involving stellate cells ${ }^{22}$ as a single responsible mechanism seems less likely than a denervation-disuse hypothesis, to explain epileptiform signs of supersensitivity. Pertinent to this point are the recent important findings of Krnjevic et al. ${ }^{17}$ showing that normal inhibitory mechanisms are still present in chronically isolated cortical slabs. Marked changes in levels of several amino acids following undercutting of the cortex have been noted ${ }^{4}$ but since these were restored with time, the supersensitivity of chronic isolation cannot be associated with such changes. Although the hyperexcitability of neurons in chronic undercut cortex may be explained by increased sensitivity of postsynaptic receptor or receptors, other changes are most certainly associated. It was recently suggested by Green et al. ${ }^{14}$ that since the $\mathrm{Na}^{+}-\mathrm{K}^{+}$-dependent ATPase activity was low in the isolated cortex, an impaired $\mathrm{K}^{+}$uptake could likely result with consequent increase in neuronal excitability. Finally, the recent micro-iontophoretic study by Krnjevic et al. ${ }^{16}$ in part indicated that there were fewer ACh sensitive neurons in isolated cortex and their responses were atypical.

However, our present data do suggest that in a cortical cholinergic system deafferentation and 'disuse' of synapses increases the sensitivity of subsynaptic membranes to putative transmitters. Conversely, long-term electrical stimulation and synaptic 'use' reduces this 'disuse'-elicited increase in sensitivity. This research thus adduces additional evidence to support the contention that electrical stimulation exerts its effect via synaptic sites.

\section{SUMMARY}

(1) An in vitro technique was used to study the binding capacity of the acetylcholinesterase (AChE)-rich synaptic membrane fraction of cat cerebral cortex for dimethyl-[ $\left.{ }^{14} \mathrm{C}\right]-\mathrm{D}$-tubocurarine. Observations were made on the effect of undercutting and long-term electrical stimulation of the undercut cortex upon this binding.

(2) Undercutting increased the binding of dimethyl-[ $\left[{ }^{14} \mathrm{C}\right]-\mathrm{D}-$ tubocurarine by $63 \%$ as compared with the contralateral control cortex. In parallel studies long-term electrical stimulation of undercut cortex appreciably reduced this expected increase.

(3) The binding of dimethyl-[14 C]-D-tubocurarine to the membranes was more directly related to membrane protein levels than to the $\mathrm{AChE}$ activity associated with them.

(4) Supersensitivity of undercut cerebral cortex is likely the result of deafferentation resulting in synaptic disuse and in a concomitantly increasing sensitivity of a postsynaptic receptor or receptors.

\section{ACKNOWLEDGEMENTS}

We wish to thank Miss Joyce Duncan and Mrs. Nell Beatty Cant for their valuable assistance with these experiments. 
The work was supported by U.S. Public Health Grants NIH NDS 04119 (LTR) and NIH NDS 06294 (OZS).

\section{REFERENCES}

1 April, R. S., AND Spencer, W. A., Disuse of stretch afferents by chronic tenotomy and deefferentation, Physiologist, 12 (1969) 159.

2 Azcurra, J. M., AND DE RoBerTIS, E., Binding of dimethyl $\mathrm{C}^{14}$-D-tubocurarine, methyl-C $\mathrm{C}^{14}$ hexamethonium and $\mathrm{H}^{3}$-alloferine by isolated synaptic membranes of brain cortex, Int. J. Neuropharmacol., 6 (1967) 15-26.

3 BERÁNEK, R., AND HNIK, P., Long-term effects of tenotomy on spinal monosynaptic response in the cat, Science, 130 (1959) 981-982.

4 BerL, S., AND McMurtry, J. G., Isolated cerebral cortex: Changes in levels of glutamic acid, glutamine, aspartic acid and $\gamma$-aminobutyric acid, Arch. Biochem. Biophys., 118 (1967) 645-648.

5 Cannon, W. B., A law of denervation, Amer. J. med. Sci., 198 (1939) 737-750.

6 Chu, N.-S., Rutledge, L. T., ANo Sellinger, O. Z., The effect of cortical undercutting and longterm electrical stimulation on synaptic acetylcholinesterase, Brain Research, 29 (1971) 323-330.

7 De Robertis, E., Alberici, M., Rodríguez de Lores ARnaiz, G., ANd Azcurra, J. M., Isolation of different types of synaptic membranes from the brain cortex, Life Sci., 5 (1966) 577-582.

8 DE RoberTIS, E., AZCURRA, J. M., AND FISZER, S., Ultrastructure and cholinergic binding capacity of junctional complexes isolated from rat brain, Brain Research, 5 (1967) 45-56.

9 De Robertis, E., AND FISzER, S., Distribution of acetylcholinesterase, proteolipids and cholinergic receptors in cat brain, J. Pharm. Pharmacol., 20 (1968) 146-148.

10 De Robertis, E., Fiszer, S., Pasquini, J. M., and Soto, E. F., Isolation and chemical nature of the receptor for D-tubocurarine in nerve-ending membranes of the cerebral cortex, $J$. Neurobiol., 1 (1969) 41-52.

11 De Robertis, E., Fiszer, S., AND Soto, E. F., Cholinergic binding capacity of proteolipids from isolated nerve-ending membranes, Science, 158 (1967) 928-929.

12 De Robertis, E., Pellegrino de Iraldi, A., Rodriguez de Lores Arnaiz, G., and Salganicoff, L., Cholinergic and non-cholinergic nerve endings in rat brain. I. Isolation and subcellular distribution of acetylcholine and acetylcholinesterase, J. Neurochem., 9 (1962) 23-35.

13 ECHLin, F. A., AND MCDonald, J., The supersensitivity of chronically isolated and partially isolated cerebral cortex as a mechanism in focal cortical epilepsy, Trans. Amer. neurol. Ass., 79 (1954) 75-79.

14 Green, J. R., Halpern, L. M., and VAN Niel, S., Alterations in the activity of selected enzymes in the chronic isolated cerebral cortex of cat, Brain, 93 (1970) 57-64.

15 KRnJevic, K., AND Phillis, J. W., Pharmacological properties of acetylcholine-sensitive cells in the cerebral cortex, J. Physiol. (Lond.), 166 (1963) 328-350.

16 Krnjević, K., Reiffenstein, R. J., ANd Silver, A., Chemical sensitivity of neurons in longisolated slabs of cat cerebral cortex, Electroenceph. clin. Neurophysiol., 29 (1970) 269-282.

17 KRnjević, K., Reiffenstein, R. J., ANd Silver, A., Inhibition and paroxysmal activity in longisolated cortical slabs, Electroenceph. clin. Neurophysiol., 29 (1970) 283-294.

18 MILEDI, R., The acetylcholine sensitivity of frog muscle fibres after complete or partial denervation, J. Physiol. (Lond.), 151 (1960) 1-23.

19 Mouren-Mathieu, A.-M., AND Colonnier, M., The molecular layer of the adult cat cerebellar cortex after lesion of the parallel fibers: An optic and electron microscope study, Brain Research, 16 (1969) 307-323.

20 Purpura, D. P., and Housepian, E. M., Morphological and physiological properties of chronically isolated immature neocortex, Exp. Neurol., 4 (1961) 377-401.

21 Rosenberg, P., and Echlin, F. A., Cholinesterase activity of chronic partially isolated cortex, Neurology (Minneap.), 15 (1965) 700-707.

22 RutledGe, L. T., Effect of stimulation on isolated cortex. In H. H. JASPER, A. A. WARD, JR. AND A. Pope (Eds.), Basic Mechanisms of the Epilepsies, Little, Brown and Co., Boston, 1969, pp. 349-355.

23 Sellinger, O. Z., Borens, R. N., ANd Nordrum, L. M., The action of trypsin and neuraminidase on the synaptic membranes of brain cortex, Biochim. biophys. Acta (Amst.), 173 (1969) 185-191.

Brain Research, 29 (1971) 331-337 
24 Sharpless, S. K., Reorganization of function in the nervous system. Use and disuse, Ann. Rev. Physiol., 26 (1964) 357-388.

25 VAlverde, F., Apical dendritic spines of the visual cortex and light deprivation in the mouse, Exp. Brain Res., 3 (1967) 337-352.

26 Vasquez, A. J., KRIP, G., AND Pinsky, C., Evidence for a muscarinic inhibitory mechanism in the cerebral cortex, Exp. Neurol., 23 (1969) 318-331.

27 WARD, A. A., JR., The epileptic neuron: Chronic foci in animals and man. In H. H. JASPER, A. A. WARD, JR. AND A. POPE (Eds.), Basic Mechanisms of the Epilepsies, Little, Brown and Co., Boston, 1969, pp. 263-288. 